\title{
DUKUNGAN SOSIAL TERHADAP MANAJEMEN PELESTARIAN LINGKUNGAN KAWASAN EKOWISATA MANGROVE TAMAN HUTAN RAYA NGURAH RAI, BALI
}

\author{
Edwina Dhyani Danaparamita ${ }^{1}$, Nadiroh $^{2}$ \\ ${ }^{1}$ Manajemen Lingkungan, Pascasarjana Universitas Negeri Jakarta, \\ Komplek Universitas Negeri Jakarta Gedung M. Hatta, Jl. Rawamangun Muka, Jakarta Timur, Indonesia \\ 13220,email: dhyaniedwina@gmail.com \\ ${ }^{2}$ Dosen Manajemen Lingkungan, Pascasarjana Universitas Negeri Jakarta, \\ Komplek Universitas Negeri Jakarta Gedung M. Hatta, Jl. Rawamangun Muka, Jakarta Timur, Indonesia \\ 13220

\begin{abstract}
Abstrak
Tujuan yang ingin dicapai dalam penulisan artikel ini adalah untuk mengetahui seberapa besar dukungan sosial masyarakat terhadap keberadaan kawasan mangrove Tahura Ngurah Rai dilihat berdasarkan perbedaan gender dan tingkat pendidikan, serta mengetahui variabel dukungan sosial yang paling berpengaruh dari pengunjung dan petugas pengelola kawasan terhadap Tahura Ngurah Rai. Penelitian dilakukan dengan cara deskriptif kuantitatif menggunakan metode survei. Hasil yang didapat adalah bahwa responden yang paling paham mengenai berbagai jenis dukungan sosial yang bertujuan untuk pelestarian kawasan mangrove adalah responden dengan pendidikan terakhir sarjana, dan perbedaan gender tidak memberikan pengaruh terhadap kepekaan responden berkaitan dengan dukungan sosial. Variabel dukungan sosial yang paling berpengaruh terhadap pelestarian kawasan mangrove Tahura Ngurah Rai adalah jenis dukungan emosional.
\end{abstract}

Kata kunci: dukungan sosial, gender, mangrove, tingkat pendidikan

\begin{abstract}
The objective to be achieved in writing this article is to find out how much the social support of the community towards the existence of the Ngurah Rai Tahura mangrove area is seen based on differences in gender and education level, as well as knowing the most influential social support variables from visitors and area management officers to the Ngurah Rai Tahura. The study was conducted by means of quantitative descriptive using survey methods. The results obtained are that the respondents who are most familiar with the various types of social support aimed at preserving the mangrove area are respondents with the most recent undergraduate education, and gender differences do not affect the sensitivity of the respondents with regard to social support. The most influential social support variable on the preservation of the Ngura Rai Tahura mangrove area is the type of emotional support.
\end{abstract}

Keywords: social support, gender, mangroves, education level 


\section{PENDAHULUAN}

Ekosistem hutan mangrove merupakan ekosistem utama pendukung kehidupan di wilayah pesisir. Hutan mangrove memiliki peran ekologis, antara lain sebagai penyedia nutrien bagi biota perairan, tempat pemijahan, nursery ground bagi berbagai macam biota, dan penahan abrasi pantai (Departemen Kehutanan, 2005). Ekowisata merupakan bentuk perjalanan wisata ke suatu lingkungan baik yang alami, buatan, ataupun yang memiliki kekhasan budaya yang bersifat informatif dan partisipatif, yang bertujuan untuk menjamin kelestarian alam dan fungsi sosial budaya. Ekowisata menitikberatkan pada tiga hal utama, yaitu keberlangsungan alam atau ekologi, keberlanjutan ekonomi dan secara psikologi, memastikan tingkat penerimaan dalam kehidupan sosial masyarakat (Satria, 2009).

Friess (2017) melakukan penelitian mengenai ekoturisme sebagai sarana pelestarian mangrove di kawasan Asia Tenggara. Hasil yang didapatkan dari penelitian tersebut adalah dengan pengelolaan yang baik, dimana terjadi kerja sama antara masyarakat dan pihak-pihak pengelola, ekowisata dapat dijadikan salah satu cara untuk melestarikan mangrove. Faizal, Hakim, dan Harahap (2017) telah melakukan penelitian mengenai faktor-faktor yang mempengaruhi tingkat partisipasi dalam pengelolaan ekowisata mangrove di

\section{Cengkrong Watulimo, Trenggalek.}

Penelitian tersebut memberikan hasil bahwa persepsi, norma yang berlaku di masyarakat, serta kepercayaan memiliki peran yang sangat penting dalam pengelolaan ekowisata mangrove di daerah tersebut. Basyuni et al (2018) meneliti tentang pengembangan pengelolaan mangrove berbasis masyarakat melalui ekowisata di Sumatera Utara, dan mendapatkan hasil bahwa berdasarkan analisis SWOT, dua lokasi yang dijadikan objek penelitian berpotensi sebagai kawasan ekowisata dengan berbagai hal yang menunjang seperti beragamnya jenis mangrove, sumber daya manusia yang berpotensi, dan akses yang mudah dicapai. Berdasarkan penelitian terdahulu yang berkaitan dengan pengelolaan atau persepsi masyarakat mengenai kawasan ekowisata mangrove, maka penulis melakukan penelitian mengenai dukungan sosial masyarakat pada kawasan ekowisata mangrove Taman Hutan Raya (Tahura) Ngrurah Rai, Bali karena subjek ini masih belum dikaji oleh penulis lain.

Hutan mangrove di Bali terbagi menjadi tiga lokasi salah satunya yaitu Taman Hutan Raya (Tahura) Ngurah Rai dengan luas 1373,5 $\mathrm{Ha}$, yang tersebar di beberapa desa di Denpasar yaitu Desa Pemogan, Sesetan, Sidakarya dan Serangan (Widagti et al. 2011). Kawasan Tahura Ngurah Rai awalnya merupakan Kawasan Hutan Prapat Banoa yang pada 
tahun 1993 berubah fungsi dari Taman Wisata Alam menjadi Taman Hutan Raya berdasarkan SK Menhut no. 544/Kpts. II/1993 tanggal 25 September 1993 (buklet). Secara geografis Tahura Ngurah Rai terletak antara $08^{\circ} 41^{\prime}-08^{\circ} 47^{\prime}$ LS dan $115^{\circ} 10^{\prime}-$ $115^{\circ} 15^{\prime}$ BT, dan secara administrasi kawasan terletak pada UPT Taman Hutan Raya, Dinas Kehutanan Provinsi Bali, Kecamatan Kuta dan Kuta Selatan, Kabupaten Badung. Kawasan mangrove Tahura Ngurah Rai merupakan daerah percontohan konservasi mangrove bagi kawasan konservasi mangrove lainnya. Selain fungsinya sebagai penahan abrasi atau gelombang laut, kawasan mangrove merupakan kawasan 'penetralisir' limbah perairan dari daratan sebelum mengalir ke laut. Daerah ini merupakan hilir dari beberapa sungai yang membawa material organik dan anorganik dari daratan serta buangan sampah dari IPAL Komunal atau Tempat Pembuangan Akhir Suwung (Mahasani, 2016). Beberapa sungai kecil di Bali membentuk aliran menuju dua sungai besar, yaitu Tukad Badung dang Tukad Mati yang mengalirkan limbah industri dan limbah rumah tangga di dalamnya (buklet).

Tujuan dilakukannya penelitian ini adalah untuk mengetahui seberapa besar dukungan sosial masyarakat terhadap keberadaan kawasan mangrove Tahura Ngurah Rai dilihat berdasarkan (1) perbedaan gender, (2) tingkat pendidikan, serta (3) variabel dukungan sosial apa yang paling berpengaruh dari masyarakat dan petugas pengelola kawasan terhadap Tahura Ngurah Rai.

\section{METODOLOGI}

Penelitian dilakukan di Tahura Ngurah Rai pada tanggal 13 Mei 2018. Alat dan bahan yang diperlukan adalah lembar kuesioner dan kamera sebagai alat dokumentasi. Narasumber untuk adalah wisatawan yang datang berkunjung ke kawasan Tahura Ngurah Rai dan petugas pengelola kawasan. Penentuan sampel dilakukan secara acak proporsional antara responden pria dan wanita. Dalam penelitian ini dipilih 10 orang responden pria dan 10 orang responden wanita. Penelitian dilakukan dengan teknik wawancara semi tersktuktur berpedoman kuesioner, pengamatan lapang, dan kajian literatur untuk melengkapi data yang dibutuhkan. Variabel yang menjadi atribut penelitian ini adalah dukungan sosial yaitu penilaian masyarakat dan upaya yang akan dilakukan untuk keberlanjutan kawasan tersebut serta peran pengelola kawasan.

Data dan informasi yang diperoleh dianalisis secara deskriptif kuantitatif menggunakan skala litert, yang tersusun berdasarkan kriteria 'selalu', 'sering', 'kadang-kadang', 'jarang, dan 'tidak pernah' dengan kisaran skala berturut-turut adalah 5, 4, 3, 2, dan 1. Selanjutnya data yang terkumpul dihitung berdasarkan jumlah 
responden yang memilih jawaban dari masing-masing pertanyaan.

\section{HASIL DAN PEMBAHASAN}

Berdasarkan hasil wawancara di lapangan terhadap 20 orang responden dengan 10 orang respoden pria dan 10 orang responden wanita, didapatkan hasil bahwa jenis kelamin atau gender tidak berpengaruh terhadap tingkat kepekaan akan dukungan sosial. Hasil tersebut didukung dengan pengujian homogenitas Fischer dengan nilai alpha 0,05 memperlihatkan nilai $\mathrm{f}$ hitung $(1,42)$ lebih kecil daripada $f$ tabel $(3,18)$.

Hasil wawancara dengan 20 orang narasumber juga membuktikan bahwa diantara keempat dukungan sosial (dukungan emosional, dukungan penghargaan, dukungan instrumental, dan dukungan informasi) masing-masing dihasilkan nilai sebesar 45\%, 29\%, 16\%, dan 10\%.

Dukungan sosial mengacu kepada kenyamanan, kepedulian, harga diri, atau bantuan yang tersedia dari orang lain dan kelompok lain (Sarafino, 2008). Menurut House dalam Depkes (2002), dukungan sosial diklasifikasikan menjadi empat jenis yaitu (1) dukungan emosional yang berupa ungkapan empati, kepedulian, dan perhatian; (2) dukungan penghargaan yang berupa ungkapan hormat atau penghargaan positif untuk orang lain, dorongan maju, atau persetujuan dengan gagasan perasaan individu dan perbandingan positif orang dengan orang lain; (3) dukungan instrumental yang mencakup bantuan langsung, misalnya dengan memberi pinjaman uang kepada orang yang membutuhkan atau menolong dengan memberi pekerjaan pada orang yang tidak memiliki pekerjaan; yang terakhir adalah (4) dukungan informatif yang mencakup pemberian nasihat, saran, pengetahuan, informasi, serta petunjuk.

Berdasarkan hasil penelitian didapatkan informasi bahwa diantara keempat jenis dukungan sosial tersebut, jenis dukungan yang paling dominan adalah berupa dukungan emosional, yaitu sebesar $45 \%$. Dukungan emosional yang dilakukan dalam rangka pelestarian kawasan wisata mangrove Taman Hutan Raya Ngurah Rai mengindikasikan bahwa sebagian besar pengunjung dan karyawan pengelola memperhatikan dengan peduli terhadap halhal menyangkut kebersihan kawasan mangrove, dimana responden akan merasa puas jika ada pihak yang bersedia memberikan kritik dan ide-ide terkait peningkatan kualitas serta pelestarian kawasan mangrove.

Poin kedua adalah dukungan penghargaan, yaitu sebesar 29\%. Hal ini menjelaskan bahwa responden cenderung mengapresiasi dengan baik segala usahausaha yang akan dilakukan untuk melestarikan lingkungan wisata mangrove Tahura Ngurah Rai. Dua poin terakhir yaitu dukungan instrumental dan dukungan 
informasi menempati nilai terendah dari keseluruhan jenis dukungan sosial. Dukungan instrumental terkait pada peran aktif pengunjung dan karyawan pengelola untuk melakukan upaya nyata terhadap keberlangsungan kawasan mangrove, dalam hal ini upaya yang dilakukan berupa pemberian dana yang bertujuan untuk membantu menjaga kebersihan kawasan Tahura Ngurah Rai, sementara dukungan informasi berfokus pada kegiatan responden untuk memberikan kritik saran, serta pengetahuan terkait keberlangsungan kawasan wisata Tahura Ngurah Rai. Rendahnya penilaian dukungan informasi ini disebabkan oleh ketidaktahuan wisatawan mengenai kawasan mengrove secara spesifik. Rata-rata pengunjung hanya mengetahui fungsi utama adanya hutan mangrove, yaitu untuk mencegah abrasi, akan tetapi saat responden memiliki kritik atau saran terkait pelestarian kawasan, baik responden yang berasal dari wisatawan, atau bahkan beberapa responden yang bekerja sebagai karyawan pengelola kawasan Tahura Ngurah Rai, tidak memiliki cukup informasi mengenai pada siapa aspirasi mereka harus disuarakan.

Berkaitan dengan hal ini, salah satu parameter yang diamati oleh peneliti adalah tingkat pendidikan. Tingkat pendidikan responden bervariasi, antara sekolah dasar hingga sarjana, namun jumlah responden yang tingkat pendidikan terakhirnya adalah sarjana jumlahnya jauh lebih sedikit dari responden yang tingkat pendidikan terakhirnya adalah sekolah dasar dan sekolah menengah pertama. Pada responden yang mengenyam pendidikan hingga sarjana, mereka cenderung mengetahui bagaimana langkah bila ingin menyampaikan aspirasi terkait pelestarian kawasan mangrove, atau kepada siapa tepatnya mereka dapat menyampaikan aspirasi mereka, sementara responden yang tidak mengetahui bagaimana langkah-langkah untuk menyuarakan aspirasi pada akhirnya akan cenderung abai.

Dilihat dari parameter gender dari seluruh responden yang diamati, disimpulkan bahwa baik responden pria atau responden wanita masing-masing tidak memiliki perbedaan secara signifikan atas kepekaan mereka terhadap keempat jenis dukungan sosial secara keseluruhan. Masing-masing responden, baik pria maupun wanita samasama memiliki kepedulian yang tinggi terhadap keberlangsungan kawasan wisata mangrove Tahura Ngurah Rai.

\section{KESIMPULAN}

Berdasarkan penelitian yang telah dilakukan, diketahui bahwa variabel jenis dukungan sosial yang paling berpengaruh diantara keempat jenis dukungan sosial adalah dukungan emosional yang secara garis besar berpusat pada sikap setuju responden pada pihak-pihak yang bersedia memberikan ideide baru untuk keberlangsungan pelestarian kawasan mangrove Tahura Ngurah Rai. Hasil 
penelitian juga menunjukkan bahwa responden yang mengenyam pendidikan lebih tinggi (sarjana) telah mengetahui dengan lebih baik upaya-upaya yang harus dilakukan dalam rangka pelestarian lingkungan. Perbedaan gender dari responden yang diamati tidak menunjukkan adanya perbedaan respon berkaitan dengan dukungan sosial, dengan kata lain, baik responden pria dan wanita memiliki keinginan dan akan memberikan usaha yang sama besar demi melestarikan kawasan ekowisata mangrove Tahura Ngurah Rai, Bali.

\section{DAFTAR PUSTAKA}

Basyuni M, et al. 2018. Developing Comunity-based Mangrove Management Trough Eco-tourism in North Sumatera, Indonesia. IOP Conference Series: Earth and Environmental Science. P 1-7.

BPKH Wilayah 6 Denpasar. 2012. Informasi Tahura Ngurah Rai. bpkh8.menlhk.go.id/pdf/karya_tulis_m andiri/buklet_tahura.pdf.

Faizal MI, Hakim L, Harahap N. 2017. Factors Affecting Levels of Participation in the Management of Mangrove as Ecotourism Attraction :
Lesson Learn from Cengkrong Watulimo, Trenggalek. Journal of Indonesian Tourism and Development Studies. Vol. 5, No 1, p 19-24.

Friess DA. 2017. Ecotourism as a Tool for Mangrove Conservation. Sumatra Journal of Disaster, Geography, and Geography Education. Vol.1, No. 1, Hal 24-35.

Mahasani IGAI, Karang IWGA, Hendrawan IG. 2016. Karbon Organik di Bawah Permukaan Tanah pada Kawasan Rehabilitasi Hutan Mangrove, Taman Hutan Raya Ngurah Rai, Bali. In proceeding Seminar Nasional Kelautan. Madura, Indonesia, 27 Juli 2016. (Hal. 33-42).

Sarafino EP, Smith, Timothy W. 2008. Health Psychology : Biopsychosocial Interaction 7th Edition. New York : John Wiley \& Sons, Inc.

Satria, D. 2009. Strategi Pengembangan Ekowisata Berbasis Ekonomi Lokal Dalam Rangka Program Pengentasan Kemiskinan di Wilayah Kabupaten Malang. Journal Of Indonesian Applied Economics, Vol.3, No. 1, Hal 37-47.

Widagti N, Triyulianti I, Manessa MDM. 2011. Changes in Density of Mangrove Forest in Nusa Lembongan, Bali. In proceeding 2nd Cresos International Symposium on South East Asia Environmental Problems and Satellite Remote Sensing. Bali, Indonesia, 2122 February 2011. (pp 171-176. 